\title{
Biomass and Carbon Stocks of Vegetation in the Marginal Uplands in Inopacan, Leyte, Eastern Visayas (Philippines)
}

\author{
Renezita S. Come, Marlito M. Bande, Manilyn Camutuhan, May \\ Joy B. Alip and Rowela Porazo
}

College of Forestry and Environmental Science, Visayas State University, Visca, Baybay City, Leyte 6521-A

\begin{abstract}
Marginal uplands are characterized by unproductive soils and low biodiversity. These areas can be a good storage of carbon for climate change mitigation if rehabilitation measures will be done. This study was conducted to quantify the biomass and carbon storage of various plant species growing in the marginal uplands in Inopacan, Leyte. Sample quadrats measuring $2 \mathrm{~m} \times 2 \mathrm{~m}$ were laid-out inside the one hectare experimental plots established in the site. Various species of grasses, herbs and shrubs were identified inside the quadrats. Using destructive sampling, biomass and carbon content in the above-ground (stems and leaves) and below-ground (roots) were determined. Soil samples were also taken for bulk density value and soil organic carbon content. Results showed that the vegetation was dominated by grass, Imperata cylindrica and shrubs namely: Melastoma malabathricum and Chromolaena odorata was 2.34 $\mathrm{Mgha}^{-1}$ and the roots was $2.28 \mathrm{Mgha}^{-1}$. Carbon stored in the stems and leaves was $1.05 \mathrm{MgCha}^{-1}$ and roots contained $1.03 \mathrm{MgCha}^{-1}$. Soils hold the highest percentage of carbon which amounted to $25.93 \mathrm{MgCha}^{-1}$. The total carbon stocks in the marginal upland in Inopacan was $28.01 \mathrm{MgCha}^{-1}$.
\end{abstract}

Key words: biomass, carbon stocks, marginal uplands, soil organic carbon, Inopacan Leyte

Correspondence : R.S. Come Address: College of Forestry and Environmental Science, Visayas State University, Visca, Baybay City, Leyte 6521-A Email: renz.come@gmail.com

DOI: $10.32945 /$ atr36s5.2014 


\section{INTRODUCTION}

The Philippines is described as a country with vast hilly lands. Out of its total land area cover of 30 million hectares, half are located in the uplands or areas with $18 \%$ slope and above. These areas were previously covered with lush vegetation, mostly forests. However, through the years, the country has experienced a very fast deforestation rate. Many of these upland areas are converted from one land use to another i.e. from forest to agricultural areas through shifting cultivation and, leaving them unproductive after being cultivated for years. Upland areas with no or less vegetation are described to be more prone to soil erosion due to its biophysical characteristics including rugged terrain and with less fertile soil. In addition, soil erosion is the most widespread process of soil degradation in the Philippines (Asio et.al., 2009). This condition is a big challenge to agriculturists, foresters and land managers since all activities in the uplands could affect lowland and coastal resources. The effect of climate change may worsen these conditions in the uplands where 25 million Filipinos who are also considered as "poorest among the poor" are living (FDC 1985, World Bank 1989).

Countrywide, rehabilitation of many uplands and making them productive and ecologically sustainable has been the priority for more than a century (Chokkalingam et.al., 2006). The government through the Department of Environment and Natural Resources (DENR) has led national reforestation programs such as the National Forestation Program in 1986, Upland Development Program, Luntiang Kalikasan, and recently, the National Greening Program. These programs aimed to rehabilitate grassland areas in the uplands and regreening of lands under public domain. Other approaches including agroforestry, establishing tree farms, and recently by adopting organic farming in the uplands were also put forward. In addition, environmental services such as carbon sequestration, reduction of soil erosion, water conservation and wildlife habitat are just few of the many benefits that we could derive from rehabilitation of these unproductive areas.

Countrywide, vast areas covered by Imperata cylindrica cover 35 million hectares (Garrity et.al., 1997) and many of these areas need immediate rehabilitation as they are located in watersheds. These areas stores and sequesters significant amount of carbon from the atmosphere. However, due to the nature of many species which can be found in these areas (i.e. fast turn-over rate), carbon cannot be stored for a longer period 
of time when compared to other land uses including plantations, agroforestry and second-growth forests. Hence, quantification of the storage and sequestration capacity of these areas is important especially that few similar studies have been conducted in Leyte. Findings may be useful for agriculturists, foresters, farmers and land managers and could serve as a baseline study to compare the carbon storage when grasslands are converted into other land uses especifically in Inopacan, Leyte.

\section{OBJECTIVES OFTHE STUDY}

The study generally aimed to quantify the carbon stocks of grassland in the marginal uplands in Inopacan, Leyte. Specifically the study aimed to:

1. Quantify the biomass and carbon stored in the above-ground (stalks and leaves) and below-ground vegetation (roots); and

2. Determine the carbon storage in the soil

\section{MATERIALS AND METHODS}

\section{Study Site}

The study area is situated in Barangay Linao, Sitio Batuan, Inopacan, Leyte. It is a 5th class municipality in the province of Leyte and one of the

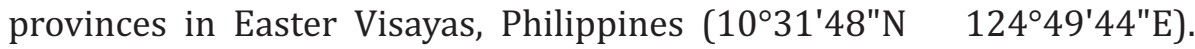
Climate is characterized with rainfall that is evenly distributed throughout the year (Type IV). The site has an average temperature of $27^{\circ} \mathrm{C}$ with a high relative humidity of $84 \%$. Maximum elevation in this site reached $1,000 \mathrm{~m}$ asl (Municipal Profile of Inopacan, Leyte n. d.). (Figure 1).

\section{Plotlay-out and Sampling}

A one hectare experimental plot was established in the site owned by a private individual. The area was divided into 25 plots measuring $20 \mathrm{~m} \mathrm{x}$ $20 \mathrm{~m}$ and was further sub-divided into 16 sub-plots measuring $5 \mathrm{~m} \times 5 \mathrm{~m}$ (Figure 2). A total of twenty four quadrats measuring $2 \mathrm{~m} \times 2 \mathrm{~m}$ nested within $5 \mathrm{~m} \times 5 \mathrm{~m}$ sub-plots were randomly laid-out. All species of grasses, herbs and shrubs found within the quadrats were identified. Also, using destructive sampling all plants contained within the randomly selected quadrats were harvested to get the fresh weight. Sub-samples were taken to the laboratory for oven-drying at $70^{\circ} \mathrm{C}$ for 48 hours or until constant 
weight was attained. In the same plots were above-ground vegetation was harvested, roots were collected up to one meter depth. Samples were washed and sieved using $2 \mathrm{~mm}$ wire mesh to separate them from the attached soil. Same methods the above-ground vegetation was applied to determine the fresh weight and oven-dried weight of roots samples.

Core sampling method was used for determining bulk density.An improvised canister with a dimension of $5.4 \mathrm{~cm}$ diameter and $6 \mathrm{~cm}$ height was used.Samples for bulk density were collected within the following soil depth: $0-10 \mathrm{~cm}, 10-30 \mathrm{~cm}, 30-50 \mathrm{~cm}$ and $50-100 \mathrm{~cm}$. Samples were carefully taken-out from the canister and placed in a sealed plastic. These were bought to the laboratory for analysis. Three (3) representative samples were taken from every depth for soil bulk density determination while four (4) samples were taken for soil organic carbon analysis. Analysis was done in the Visayas State University, Baybay City, Leyte Central Analytical Laboratory.

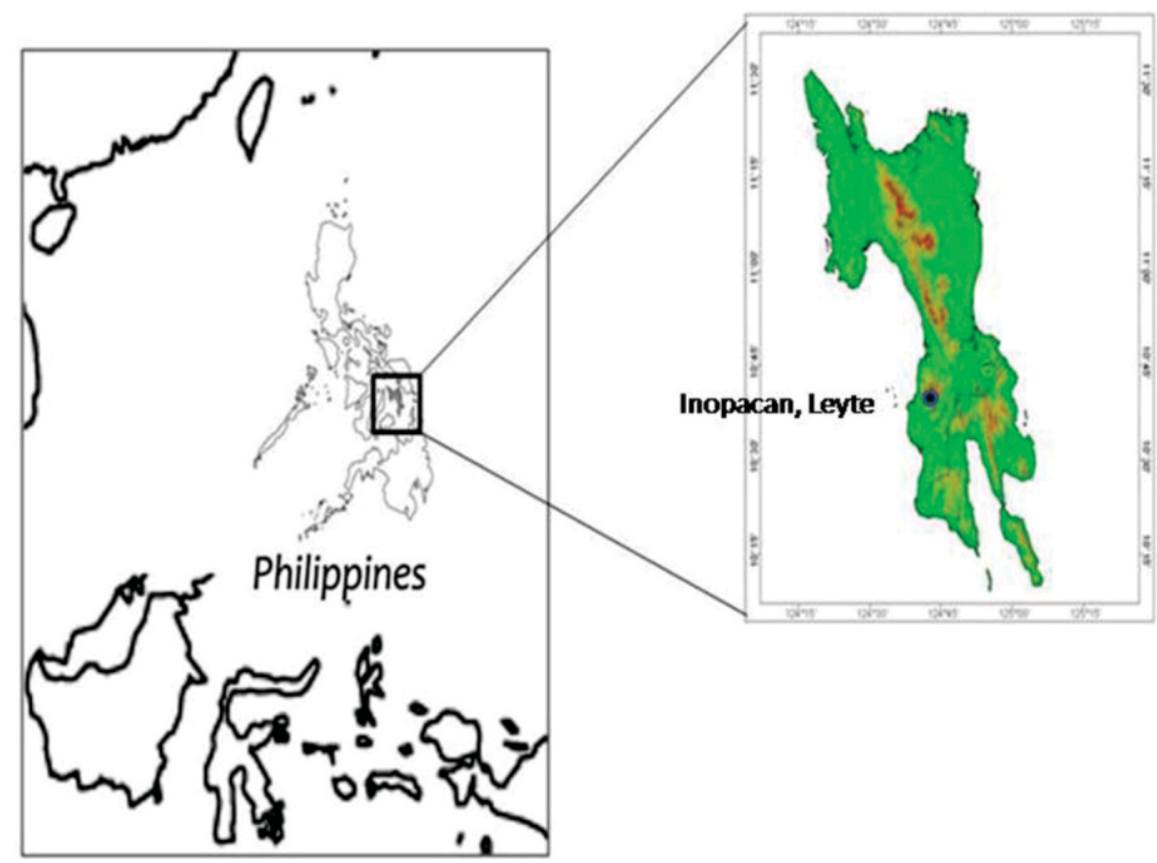

Figure 1. Location map of the study area in Sitio Batuan, Brgy. Linao, Inopacan, Leyte. 


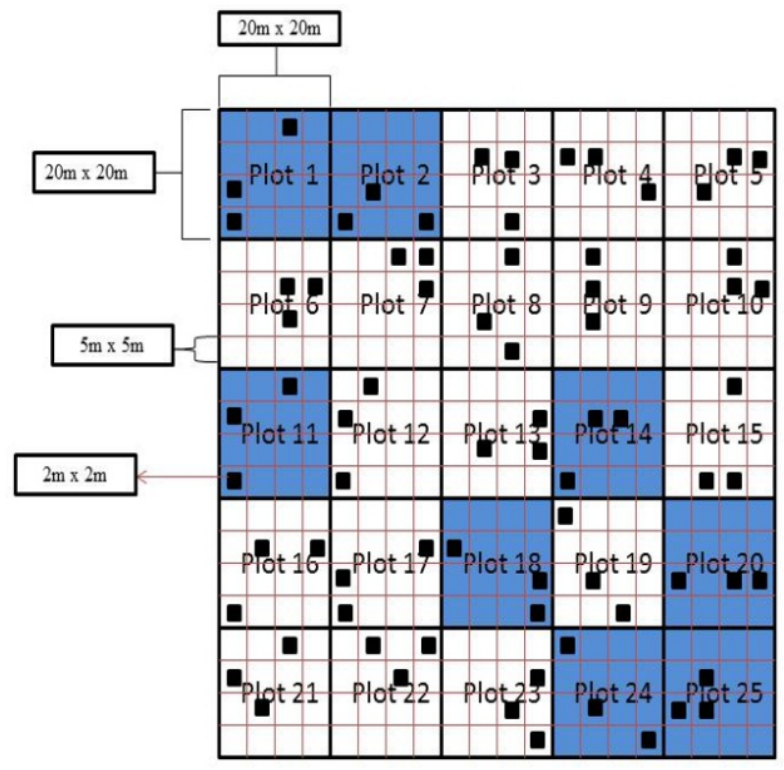

Figure 2. Lay-out of the one hectare experimental plots.

Data Analysis

Descriptive statistics including mean and standard deviation was performed for this study. In addition, the following formula were used in the analysis and interpretation of data.

Above-Ground and Below-Ground Biomass

Biomass values for grass, shrubs and herbs were calculated using the following formula:

Equation 1

$$
\mathrm{ODW}(\mathrm{g})=\frac{\mathrm{TFW}-\left(\mathrm{TFW}^{*}(\mathrm{SFW}-\mathrm{SODW})\right)}{\mathrm{SFW}}
$$

Where:

ODW = Oven-Dry Weight

TFW $=$ Total Fresh Weight

SODW= sample oven-dry weight 
To calculate the carbon storage in plants:

Equation 2

Total $\mathrm{C}=$ Biomass $*$ carbon content of plant tissue (we used $45 \%$ as Default value)

Soil

Equation 3

Bulk density $\left(\mathrm{gcm}^{-3}\right)=\frac{\text { Dry weight of soil }(\mathrm{g})}{\text { Volume of the canister }(\mathrm{cc})}$

The dry weight of soil and carbon stock was computed using the following formulae:

\section{Equation 4}

Soil mass at specified depth $(\mathrm{Mg})=$ Bulk density at specified depth $(\mathrm{Mg}$ $\mathrm{m}^{-3}$ ) $\times 10,000 \mathrm{~m}^{2} \mathrm{x}$ depth (m)

Soil organic carbon stocks $(\mathrm{Mg})$

\section{Equation 5}

soil mass at specified depth $(\mathrm{Mg}) \mathrm{x}$ Total SOC $\left(\mathrm{MgCha}^{-1}\right)=\frac{\% \text { organic carbon at specified depth }}{100}$ 


\section{RESULTS AND DISCUSSION}

Species composition. Results from this study showed that the study area is mainly dominated by cogon (Imperata cylindrica) with $16.09 \%$ of the total vegetation. Cogon is characterized as very flammable, and their occurrence indicates that the area has an acidic soil. This was followed by shrub species namely:hantotoknaw (Melastoma malabathricum),hagonoy (Chromolaema odorata) and malagabon or kukug banug (Elephantopus specatus) were all of them comprised per species. Other plant species that are present in the area includes mani-mani (Desmodium triflorum),bugang/talahib (Saccharum spontaneum), bario-bario (Piper aduricum), malacogon, crops like camote, cassava, pineapple and banana. Also, few trees of Gmelina arborea were observed in the area, however, trees are planted outside the one hectare study plot. A total of 25 plant species were identified in the study site (Table 1 ).

Above ground biomass and carbon stocks. The computed biomass of the above ground part of the grassland area has a total of $2.34 \mathrm{Mgha}^{-1}$. It ranges from 0 to $0.50 \mathrm{Mgha}^{-1}$. This result was very dependent to the kind of species that were found in the plot and how much the samples that were able to take from the plot (Pulhin, 2008). For example, in plot 18 there were only 3 species of grass that were collected. This is because plot 18 has been cultivated for crop plantation purposes. On the other hand, plot 11 has more 10 species of grass and it has the highest total fresh weight which is $7.94 \mathrm{Kgha}^{-1}$. The total carbon storage of above-ground vegetation has amounted up to $1.05 \mathrm{Mgha}^{-1}$.

Below ground biomass and carbon stocks. Root biomass has a total of $2.28 \mathrm{Mgha}^{-1}$. Value ranges from 0.01 to $0.30 \mathrm{Mgha}^{-1}$. The result can be explained by the high amount of roots that were taken from the plots. The carbon storage of the roots has a total of $1.03 \mathrm{Mgha}^{-1}$ (Figure 3). Root biomass is almost has similar amount to the biomass in the above-ground vegetation. This is due to its roots system in which grass has a short length of roots and it cannot hold carbon for longer period of time, compared to the root system of trees which can penetrate deeper and has longer length, so it has more capacity to stored carbon for long time.

As stated by Lugo and Brown (1992) in a system biomass has different values, in which resulted from the different degrees of anthropogenic activity and other natural disturbances. A grassland area with higher 
biomass densities means its experiencing lesser disturbances. While if the area have lower biomass densities that means it is experiencing higher disturbance such as frequent burning of the grasses.

Likewise, many factors could affect the biomass and carbon storage of vegetation and one of that is the weather, which is the wet and dry season. Biomass and carbon storage in rainy season is indeed greater than the biomass and carbon storage that is being accumulated during summer. For in rainy season the grassland vegetation is faster to regenerate, hence higher biomass is expected. In addition, carbon storage during this season is also greater because its result is very dependent to the amount of biomass gathered.

Bulk density and soil organic carbon. The bulk densities of the soil in all sampled plots ranged from $0.30 \mathrm{gcc}^{-1}$ to $0.70 \mathrm{gcc}^{-1}$. Plot 7 contains both the lowest and highest bulk density of the soil. It was noted that all of the plots have bulk densities of $>0.90 \mathrm{gcc}^{-1}$, which indicates that soil bulk densities derived from the grassland is still compacted and less disturbed. This fits the typical characteristic of grassland areas in the Philippines wherein high soil bulk density indicates that site is disturbed (Pulhin, 2008).

Soil organic carbon (SOC) ranged from 16.61 to $30.34 \mathrm{MgCha}^{-1}$ found in various soil layers where samples were taken. On the other hand, bulk density ranged from 1.05 to $1.22 \mathrm{~g} \mathrm{cc}^{-1}$ (Table 2). Carbon storage in soils at various depths in grasslands showed no pattern and the average was 25.93 $\mathrm{MgCha}^{-1}$. Results of the study showed that soil holds the highest amount of carbon. The carbon stored that was derived from this study is almost half to the results of studies that were conducted in Leyte, which have a carbon density value of $52.70 \mathrm{Mgha}^{-1}$ (Lasco, et.al. 2000).

Table 2. Sample bulk density and carbon storage of the soil.

\begin{tabular}{lcc}
\hline Soil Layers & $\mathrm{BD}\left(\mathrm{g} \mathrm{cc}^{-1}\right)$ & $\mathrm{C}\left(\mathrm{MgCha}^{-1}\right)$ \\
\hline $0-10 \mathrm{~cm}$ & 1.05 & $16.61 \pm 2.15$ \\
$10-30 \mathrm{~cm}$ & 1.22 & $25.90 \pm 9.11$ \\
$30-50 \mathrm{~cm}$ & 1.07 & $20.91 \pm 13.96$ \\
$50-100 \mathrm{~cm}$ & 1.14 & $30.34 \pm 22.39$ \\
\hline
\end{tabular}

Total carbon storage of grassland. Overall, the one-hectare grassland stored the total carbon stocks of $28.01 \mathrm{Mgha}^{-1}$. Various carbon pools include soils with $25.93 \mathrm{Mgha}^{-1}$, above-ground biomass (stems and leaves) with $1.05 \mathrm{Mgha}^{-1}$ and below-ground biomass (roots) with $1.03 \mathrm{Mgha}^{-1}$. Soil stores the highest amount of carbon while above-ground and below- 
Table 1. Description, number of occurrence and frequency of plant species in the study site.

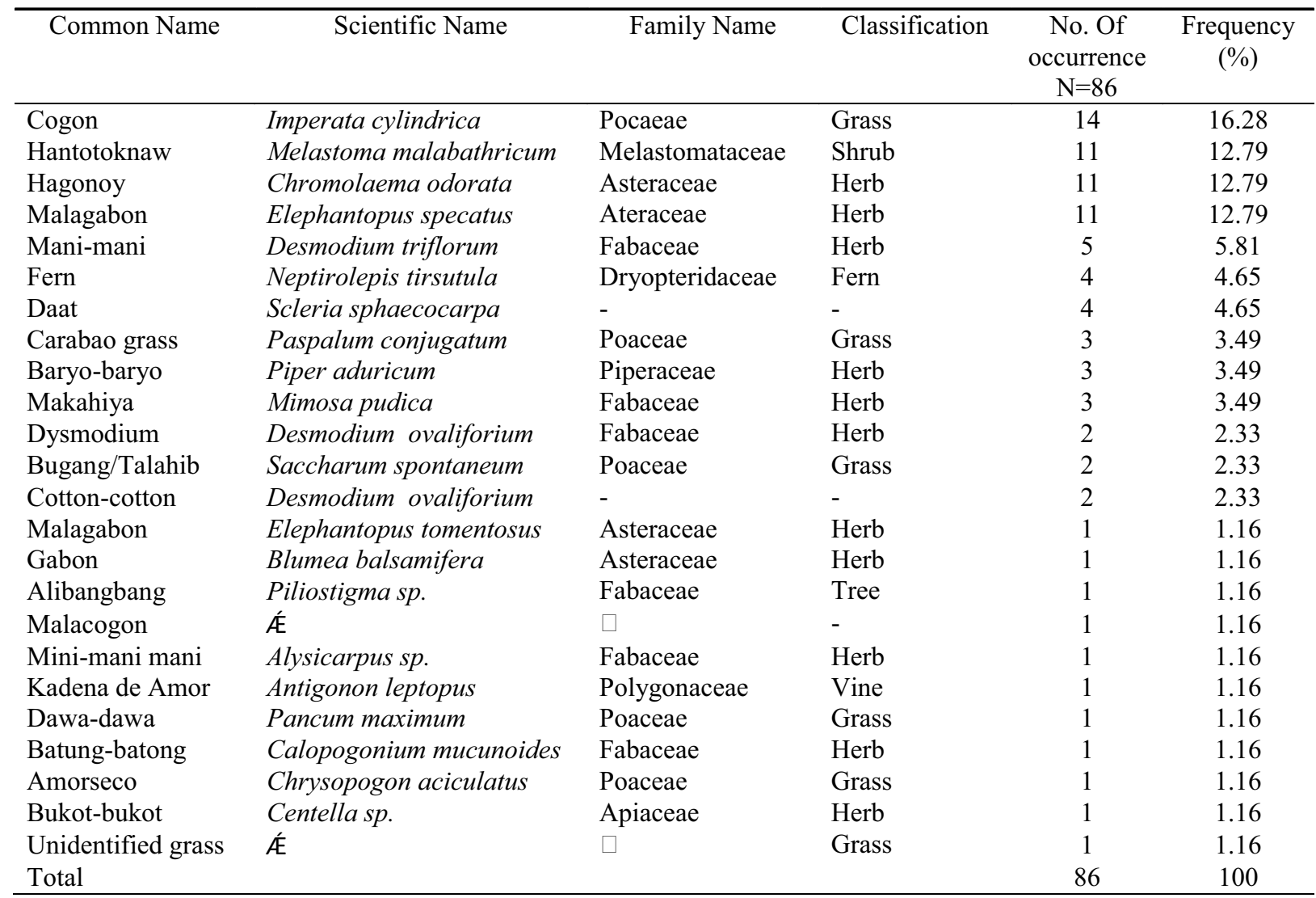


ground vegetation stored more or less the same amount of carbon. Soils are known to store more organic carbon and holds it for a longer period of time. In addition, the capability of the soil to store soil organic carbon is being influenced by the following factors: (1) mean annual precipitation; (2) degree of forest disturbance; (3) extent of land use change (Lugo and Brown, 1993). It was cited by Pulhin (2008) that in order to enhance soil sequestration the following strategies must be done. (1) reduce erosion through reforestation; (2) improving soil fertility; (3) reduce shifting cultivation; (4) remove marginal lands from agricultural production; (5) retaining forest litter and debris (Lasco et al., 2000).

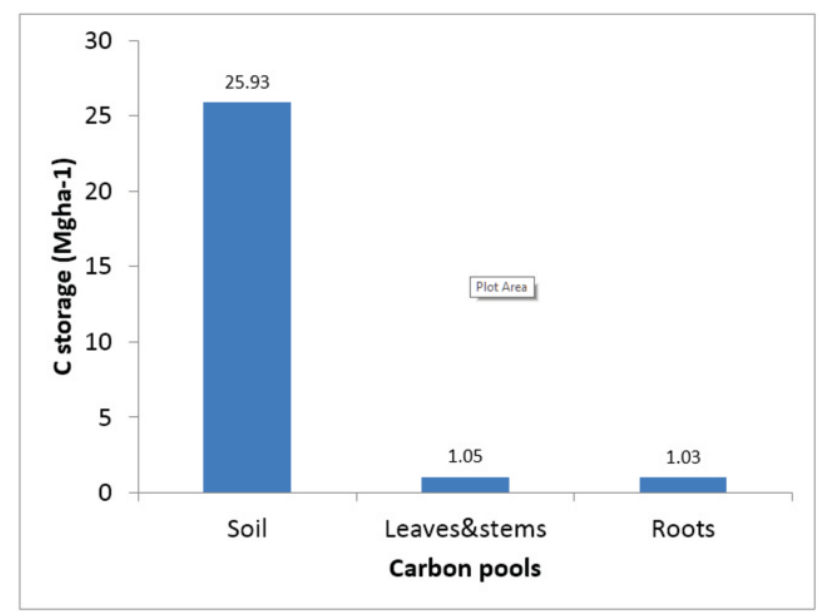

Figure 3. Total stocks in the various carbon pools in the study area in Inopacan, Leyte

\section{IMPLICATIONS AND RECOMMENDATIONS}

Important baseline data on the carbon storage capacity of grasslands in marginal uplands in Inopacan, Leyte was derived from this study. Results showed that soil is an important carbon pool and has higher capacity to store carbon than above-ground and below-ground (roots) pools. Since grasslands are known to have high turn-over rate due to their nature and prone to burning and grazing, carbon cannot be stored for a longer period of time compared to other land uses including agroforestry and tree plantations. It is therefore recommended that marginal uplands in Inopacan be converted into more productive and diverse ecosystem in order to maximize the benefits of the areas both ecologically and economically. Further studies including quantification of carbon in 
different grassland communities is also recommended. Carbon stocks assessment of marginal uplands during rainy season could also be conducted to compare the results of this study. Other important species of grasses, shrubs or herbs might be present during this season which were not documented during the conduct of this study.

\section{REFERENCES}

ASIO V. B., JAHN, R., PEREZ, F.O., NAVARETTE, I.A. AND ABIT, S.M.JR. 2009. A Review of Soil Degradation in the Philippines. Annals of Tropical Research 31(2):69-94.

CHOKKALINGAM, U., CARANDANG, A.P., PULHIN, J.M., LASCO, R.D., PERAS, R.J. and TOMA, T., 2006. One Century of Forest Rehabilitation in the Philippines: Approaches, outcomes and lessons. SMK Grafika Desa Putera, Jarakta, Indonesia. 132 pp.

FORESTRY DEVELOPMENT CENTER (FDC). 1985. A critical look at the upland livelihood programs in the Philippines. Policy Paper No. 16. Forestry Development Center, College of Forestry and Natural Resources, University of the Philippines Los Baños.

GARRITY, D.P., SOEKARDI, M., van NOORDWIJK, M., de la CRUZ, R., PATHAK, P.S., GUNASENA, H.P., van SO, M.N., HUIJUN, G. and MAJID, N.M. 1997. The Imperata grasslands of tropical Asia: area, distribution and typology. Agroforestry Systems, 36: 3-29.

LASCO, R.D., J.S. LALES., M.T. ARNUEVO., I.Q. GUILLERMO., DE JESUS, A.C., MEDRANO, R., BAJAR, O.F. and MENDOZA, C.V. 2000. Proceedings World Geothermal Congress 2000. Kyushu-Tohoku, Japan, May 28-June 10, 2000.Pp.6.

LUGO, A.E. and S. BROWN. 1992. Tropical Forest as Sinks of Atmospheric Carbon. Forest Ecologyand Management., 54:239-255.

LUGO, A. E. and BROWN. 1993. Management of Tropical Soils as Sinks or Sources of Atmospheric Carbon. Plant and Soil. Kluwer Academic Publishers. Netherlands. 149: 27-41. 
Biomass and Carbon Stocks of Vegetation in the Marginal Uplands

Municipal Profile of Inopacan, Leyte n.d.pp. 53.

PULHIN, F. 2008. Carbon storage of the grassland areas of Ikalahan Ancestral Domain, Nueva Viscaya, Philippines. Published by World Agroforestry System. Bogor, Indonesia. WP 32: p 32.

QUIMIO, J. 1996. Grassland Vegetation in Western Leyte, Philippines. Doctoral dissertation, Freiberg University in Germany.

WORLD BANK. 1989. Philippines, environment and natural resources management study: a World Bank country study. The World Bank, Washington, D.C., USA. 